\title{
FAKTOR PENDUKUNG DAN PENGHAMBAT PERKEMBANGAN AGAMA LOKAL KAHARINGAN PADA ETNIS DAYAK
}

\author{
Supporting and Hampering Determinants of Local Religions "Kaharingan" on Dayak Ethnic
}

\author{
Josef Dudi ${ }^{1}$ \\ 1Sekolah Tinggi Pastoral (STIPAS) Palangkaraya \\ e-mail: ${ }^{1}$ bernadetha_boli@yahoo.com
}

\begin{abstract}
Abstrak
Penelitian ini bertujuan mengetahui faktor pendorong dan penghambat perkembangan agama lokal Kaharingan pada etnis Dayak di Provinsi Kalimantan Tengah-Indonesia. Penelitian ini menggunakan metode penelitian kualitatif dengan pendekatan grounded. Berdasarkan hasil penelitian dapat disimpulan: Pertama, faktor pendukung keberadaan agama lokal Kaharingan, yaitu: 1) adanya realitas bahwa kepercayaan Kaharingan sangat kuat mempengaruhi karakter sosial dan pranata sosial peradaban orang Dayak Ngaju, 2) agama lokal Kaharingan menjadi pusat sentuh agama-agama lain, dan 3) adanya kademangan yang dipercayai sebagai lembaga sosial sekaligus lembaga religius. Kedua, setidaknya ada tiga faktor penghambat perkembangan agama lokal Kaharingan pada Etnis Dayak, yaitu 1) perubahan kultural, 2) intervensi pemerintah terhadap lembaga adat, dan 3) pudarnya mentalitas "betang".
\end{abstract}

Kata Kunci: Agama lokal, Kaharingan, Dayak Ngaju

\begin{abstract}
This study aims to determine the driving and inhibiting determinants of the development of local religions Kaharingan on Dayak ethnic in the province of Central Kalimantan-Indonesia. This research employed a qualitative research method with a grounded approach. Based on the research result, it concludes: Firstly, the supporting factor of Kaharingan local religion existence are: 1) existence of reality that Kaharingan trust very strongly influencing social character and social order of civilization of Dayak Ngaju people, 2) Kaharingan local religion becomes the center of a touch of other faith, and 3) the existence of kademangan which is believed to be a social institution as well as a religious institution. Second, at least three factors are inhibiting the development of local religions Kaharingan on Dayak ethnic, namely 1) cultural change, 2) government intervention against customary institutions, and 3) fading mentality "betang".
\end{abstract}

Keywords: Local Religion, Kaharingan, Dayak Ngaju

\section{A. PENDAHULUAN}

Pluralitas adalah suatu realitas sosial. Pluralitas merupakan suatu kebenaran alamiah (O'Dea, 1996: 61). Pluralitas harus dihadirkan untuk menciptakan tertib sosial. Keanekaragaman agama sangat diperlukan agar komunitas dapat eksis (Tubbs dan Moss, 2000:61). Akan tetapi, pluralitas merupakan ancaman. Pluralitas lebih sering menyakitkan daripada menyenangkan (Juliawan, 2004).

Salah satu unsur keragaman yang paling peka dan sangat potensial memunculkan konflik 
adalah agama. Filosof sosial telah banyak membahas bahwa pluralitas agama sering mempunyai efek negatif terhadap kesejahteraan masyarakat dan individu. Isu-isu agama menjadi salah satu masalah penyebab perang. Keyakinan agama sering menimbulkan sikap tidak toleran. Loyalitas agama hanya menyatukan beberapa orang tertentu dan memisahkan yang lainnya (O'Dea, 1996:139). Jonathan Wift dengan nada sinis mengatakan: “Kita mempunyai agama hanya untuk membuat kita saling membenci, namun tidak cukup membuat kita untuk saling mencintai" (O’Dea, 1996:141).

Sejumlah pakar pluralis agama berusaha menelaah secara mendalam substansi pluralitas agama. Salah satu faktor dibutuhkan tesis pluralisme agama adalah kode etik yang samasama dimiliki oleh berbagai tradisi keagamaan. Menurut Caputo (2003:134): "Agama-agama, dalam bentuk plural, bersifat unik, tetapi tanpa klaim kepemilikan eksklusif atas kebenaran".

Kerusuhan besar bernuansa agama yang di Indonesia terjadi sejak tahun 1998 adalah konflik Ambon, konflik Sambas, konflik Pontianak, kasus Ketapang, kasus Kupang, kasus Mataram, kasus Sampit (Herts, 2003), dan konflik Poso. Konflikkonflik tersebut telah menewaskan ribuan orang. Ribuan orang mengungsi dan ketakutan di kampung halamannya sendiri.

Ketika kerusuhan bermotif SARA (Suku Agama, Ras, Antargolongan) di Indonesia berkecamuk, kebanyakan orang demikian sibuk mencari penyebab kerusuhan. Namun, orang lupa bahwa ada sejumlah suku di pelosok Indonesia yang hidup damai dalam perbedaan berabad-abad lamanya. Mereka jarang sibuk mencari penyebab mengapa sejumlah suku yang plural itu hidup harmoni? Salah satu contoh dari pernyataan terakhir itu adalah masyarakat di Desa Sei Gohong Kecamatan Bukit Batu (Kota Palangka Raya) Provinsi Kalimantan Tengah.

Sei Gohong adalah sebuah desa yang memperlihatkan karakter sosial yang tipikal oleh karena pluralitas agama yang hidup secara harmonis. Fenomena itu, tentu tidak berarti bahwa
Sei Gohong tidak mengalami persaingan dan konflik. Namun, mekanisme penyelesaian konflik sudah tertata dalam ruang sosial yang unik dan istimewa.

Ada empat agama yang hidup berdampingan dan eksis di tengah perbedaan di Sei Gohong, yakni Agama lokal Kaharingan, Islam, Protestan, dan Katolik. Agama lokal Kaharingan dianut oleh masyarakat yang berasal dari satu etnik yakni etnik Dayak. Namun, agama lokal tersebut sampai saat ini dirasakan sulit berkembang, karena berbagai hal, seperti perkembangan agama islam, kristen, dan katolik.

Menurut Durkheim sebagaimana dikutip oleh O’Dea, (1995:215) agama adalah suatu "sistem kepercayaan dan praktik yang telah dipersatukan yang berkaitan dengan hal-hal yang kudus, kepercayaan-kepercayaan dan praktik-praktik yang bersatu menjadi suatu komunitas moral yang tunggal."

Agama dan masyarakat memiliki hubungan yang erat. Hal itu mencerminkan bahwa agama merupakan implikasi dari perkembangan masyarakat. Agama adalah sebuah fakta sosial yang harus diterangkan oleh fakta-fakta sosial lainnya. Sifat kudus yang dimaksud Durkheim dalam kaitannya dengan pembahasan agama bukanlah dalam artian yang teologis, melainkan sosiologis. Sifat kudus itu dapat diartikan bahwa sesuatu yang "kudus" itu "dikelilingi oleh ketentuan-ketentuan tata cara keagamaan dan larangan-larangan yang memaksakan pemisahan radikal dari yang duniawi." Sifat kudus ini dibayangkan sebagai suatu kesatuan yang berada di atas segala-galanya. Durkheim menyambungkan lahirnya pengkudusan ini dengan perkembangan masyarakat.

Selain sifat "kudus", suatu agama selalu melibatkan ritual tertentu. Ada dua jenis praktik ritual yang terjalin dengan sangat erat yaitu pertama, praktik ritual negatif yang berwujud dalam bentuk pantangan-pantangan atau larangan-larangan dalam suatu upacara keagamaan; kedua, praktik ritual positif yang berwujud dalam bentuk upacaraupacara keagamaan itu sendiri. 
Hubungan antara agama dengan masyarakat juga terlihat di dalam masalah ritual. Kesatuan masyarakat sangat tergantung kepada conscience collective, dan agama nampak memainkan peran ini. Masyarakat menjadi "masyarakat yang beragama" karena para anggotanya taat kepada kepercayaan. Ritual, yang terwujud merupakan orde moral yang ada. Di sini agama sebagai alat integrasi masyarakat, dan praktik ritual secara terus menerus menekankan ketaatan manusia terhadap agama. Dengan begitu, praktik ritual secara bersama-sama turut serta di dalam memainkan fungsi penguatan solidaritas.

Agama merupakan bagian terpenting dari kebudayaan. O'Dea (1995:215) mengatakan, agama adalah unsur sentral dalam kebudayaan. Ajaran konkrit yang terkandung di dalamnya bisa saja harmonis atau ada konflik dengan situasi yang ada dalam masyarakat.

Menurut Northcott (2000:267), konstruksi Spengalaman manusia terbentuk dari agama yang dianut. Agama adalah salah satu bentuk konstruksi sosial. Setiap agama pasti mempunyai manifesto sosio-kultural. Menifesto sosio-kultural itu biasanya terjadi pada suatu lokasi tertentu yang menjadi pusat dari segala kegiatan agama (rumah Allah, gereja, pura, masjid, dan sebagainya).

Aslan (2004:164) membeberkan bahwa

dalam berbagai agama, aturan itu ditegaskan sebagai suatu prinsip etika. Dalam kitab suci Hindu Mahabharata dikatakan bahwa: "Seseorang tidak boleh melakukan sesuatu kepada orang lain yang dipandangnya melukai dirinya sendiri." Dalam kitab suci Jaina, Sutra Kritoga dikatakan bahwa: "Seseorang harus memperlakukan semua mahkluk di dunia sebagaimana dirinya ingin diperlakukan". Dalam Taoisme, Tha Shang, dikatakan, “Orang baik akan menganggap keuntungan orang lain seolaholah miliknya sendiri, dan kerugian mereka sebagai kerugiannya". Dadistan-i dini zoroaster menyatakan, "Watak itu bagus selama ia tidak melakukan sesuatu bagi orang lain yang bagi dirinya sendiri tidak baik". Yesus mengatakan, "Sebagaimana kamu menginginkan orang lain memperlakukanmu, maka perlakukan mereka seperti itu". Dalam sebuah hadits Nabi Muhammad menyatakan, "Seseorang tidaklah disebut Mukmin sejati kecuali jika menginginkan bagi saudaranya apa yang diinginkan oleh dirinya".

Kimball (2003:84) mengatakan, dalam setiap agama, klaim kebenaran merupakan fondasi yang mendasari keseluruhan struktur agama. Namun, ketika interpretasi tertentu atas klaim tersebut menjadi proposisi-proposisi yang menuntut kebenaran tunggal dan diperlakukan sebagai doktrin kaku. Kecenderungan tersebut merupakan tanda-tanda awal kejahatan yang menyertainya. Menurut Tracy (1987), di antara agama-agama yang ada di dunia ini memang tidak ada yang memiliki esensi tunggal. Ada perbedaan penafsiran tentang Tuhan itu sendiri: God, Emptiness, Suchness, the One, Nature, the Many. Ada perbedaan pemahaman mengenai apa yang diwahyukan oleh Tuhan tentang Tuhan dan tentang diri kita dalam hubungan harmoni dan disharmoni dengan Tuhan.

Penelitian ini bermaksud menjawab pertanyaan, faktor-faktor apakah yang mendorong dan menghambat perkembangan agama lokal Kaharingan pada etnis Dayak di Kalimantan Tengah?

\section{B. METODE PENELITIAN}

Penelitian ini dilaksanakan di desa Sei Gohong Kecamatan Bukit Batu Kota Palangka Raya Propinsi Kalimantan Tengah, Indonesia. Teknik pengumpulan data yaitu pengamatan partisipatif, depth interview, dan dokumentasi. Keabsahan data dilakukan dengan menggunakan metode triangulasi data yang meliputi, cek, recek, dan kroscek, serta memperlama saat berada di lokasi penelitian. Analisis data dilakukan dengan menggunakan empat tahap penelitian kualitatif yang meliputi koleksi data, reduksi data, klasifikasi data, dan penarikan kesimpulan.

\section{HASIL DAN PEMBAHASAN}

Hasil dan pembahasan berisi hasil-hasil temuan penelitian dan pembahasannya. Tuliskan temuan-temuan yang diperoleh dari hasil-hasil 
penelitian yang telah dilakukan dan harus ditunjang oleh data-data yang memadai. Hasil-hasil penelitian dan temuan harus bisa menjawab pertanyaan atau hipotesis penelitian di bagian pendahuluan.

\section{Faktor Pendukung Perkembangan Agama Kaharingan}

Secara kultultural, Sei Gohong, Kecamatan Bukit Batu, Kota Palangka Raya, Kalimantan Tengah, Indonesia berjarak $44 \mathrm{~km}$ dari ibu kota Palangka Raya sehingga mereka setiap hari berhubungan dengan beberapa hal yang bersifat modern. Masyarakat Sei Gohong telah terbuka dalam hal orientasi pekerjaan, mentalitas, dan pilihan barang konsumsi. Keadaan demikian didukung oleh sarana komunikasi modern yang menawarkan gaya hidup dan selera baru.

Sejumlah 327 televisi sebagai agen budaya yang menghantar mereka berbagai perpektif dalam kognisi mereka, 20 unit parabola yang mendekatkan jarak dunia manapun dan 350 handphone yang digunakan sebagai sarana komunikasi paling praktis. Sarana-saran tersebut di atas mempercepat perubahan kultural dalam masyarakat Sei Gohong. Artinya, secara kultural masyarakat Sei Gohong sedang melakukan perjalanan dari old society menuju modern society.

Pluralisme agama di kalangan masyarakat etnik Dayak Ngaju, khususnya di Kelurahan Sei Gohong, ditunjukkan adanya pertemuan antar pemeluk agama dan kepercayaan yang berbeda yang dipayungi oleh kepercayaan lokal Kaharingan. Secara kuantitas jumlah penganut berdasarkan agama di Sei Gohong sebagai berikut: Penduduk beragama Islam sebanyak 661 orang, penganut Kristen Protestan sebanyak 593 orang, penganut Katolik sebanyak 40 orang, penganut agama Budha sebanyak 1 orang, dan penganut agama lokal Kaharingan sebanyak 92 orang. Sedangkan rumah ibadah berupa Masjid sebanyak 1 buah, langgar sebanyak 2 buah, dan Gereja Protestan sebanyak 5 buah.

Agama lokal Kaharingan dapat hidup dan berkembang di Sei Gohong karena didukung oleh beberapa hal. Pertama, bahwa kepercayaan Kaharingan sangat kuat mempengaruhi karakter sosial orang Dayak Ngaju di Sei Gohong. Ada satu alasan mendasar mengapa kepercayaan Kaharingan demikian kuat mempengaruhi pranata sosial peradaban Dayak, karena Kaharingan dipahami dan diamalkan sebagai bagian dari kebudayaan atau tradisi religi dalam seluk-beluk peradaban Dayak. Ranying Hatalla Langit yang dipercaya menguasai segala makhluk di bumi dan merupakan awal dan akhir semua kejadian di dunia. Ranying Hatalla Langit juga diyakini sebagai pewahyu ajaran bagaimana cara hidup di bumi yang kemudian dilembagakan dalam ritual.

Kedua, agama lokal Kaharingan menjadi pusat sentuh agama-agama lain. Dalam arti, orang etnis dayak, meskipun sudah memeluk agama di luar agama lokal Kaharingan, tetapi mereka tetap saja tidak dapat lepas dari prinsip-prinsip hidup orang dayak yang selalu dilingkupi adat dan budaya Etnis Dayak Ngaju. Dengan kata lain, agama lokal Kaharingan merupakan religiusitas orang dayak yang tidak mudah dipahami dengan pengertian agama dalam konsteks alkitabiah. Karena, jauh sebelum suku non Dayak masuk ke Sei Gohong, orang Sei Gohong sudah menganut kepercayaan kaharingan.

Ketiga, adanya kademangan yang dipercayai sebagai lembaga sosial sekaligus lembaga religius. Kekuatan lembaga ini bukan terletak pada pemimpinnya, tetapi adanya peran ganda lembaga ini yang dipercayai tidak hanya sebagai lembaga sosial tetapi juga sebagai lembaga religius. Sebagai lembaga sosial, kedemangan menjadi sumber terpenting dalam pranata sosial orang Dayak (di Sei Gohong). Sebagai institusi religius kedemangan diapandang sebagai titisan Ranying Hatalla. Dengan demikian, demang (kepala adat) menjadi titisan Ranying Hatalla. Dalam hubungan demikian, bahadat dan titah sang Demang merupakan bagian dari wahyu Ranying Hatalla. Lembaga ini yang paling langsung menginternalisasikan nilai-nilai kedayakan (peradaban Dayak). Di samping itu, lembaga kedemangan dapat membabtis orang luar 
menjadi orang Sei Gohong melalui mamapas lewu atau maja misek (nikah adat). Dengan demikian, lembaga kedemangan adalah lembaga yang sang kuat pengaruhnya dalam menyatuhkan keragaman dalam masyarakat Sei Gohong.

\section{Faktor-Faktor Penghambat Perkembangan Agama Kaharingan}

Sedikitnya adan tiga faktor penghambat perekmbangan agama Kaharingan pada Etnis Dayak. Pertama, Perubahan Kultural, kedua intervensi pemerintah terhadap lembaga adat, dan ketiga, pudarnya mentalitas "betang".

Pertama, kepribadian Dayak dengan segala pranata sosialnya sulit sekali bertahan di tengah arus perubahan kebudayaan modern. Perubahan otoritas moral dari moral agama ke moralitas individual yang rasional. Walaupun demikian, moralitas individual itu, menyimpan satu ciri khas dari agama yaitu "kesalehan". Moralitas individual itu memiliki sifat kudus, karena moralitas itu hanya bisa hidup apabila orang memberikan rasa hormat kepadanya dan menganggap bahwa hal itu tidak bisa diganggu-gugat. Hal ini merupakan suatu bentuk "kesalehan" yang dinisbahkan oleh masyarakat kepada moralitas individual tersebut. Akan tetapi, kekudusan personal hanya terekspresi secara benar dalam praktik kehidupan masyarakat yang selalu berada dalam perubahan.

Perubahan kuantitatifnya terlihat dari jumlah penganut Kaharingan yang semakin berkurang. Sampai penelitian ini dilakukan penganut Kaharingan hanya 92 orang. Masyarakat dapat ditarik untuk mengikuti agama lain yang kemudian memengaruhi sedikit demi sedikit masyarakat di Sei Gohong.

Gereja mempunyai andil besar untuk melenyapkan atau mendistorsi peradaban Dayak yang bersumber dari Ranying Hatalla. Bagi mereka menjadi Kristen berarti memecatkan diri dari Dayak asli. Menjadi Kristen adalah menjadi orang lain. Kegelisahan ini jauh-jauh hari telah ditulis Tjilik Riwut (2003:540). Ia menulis, setelah orang Dayak mulai membuka hati, tertarik dan ingin tahu, kemudian belajar tentang ajaran Kristen, pihak
Kristen di kalimantan mengeluarkan aturan ungkup (aturan Sidang jemaat Orang Kristen) yang antara lain isinya mengatakan bahwa salah satu prasyarat pengajaran pembabtisan harus menyatakan secara terbuka keinginannya untuk belajar dengan sungguh-sungguh, dan berjanji senantiasa ikut kebaktian, meninggalkan perbuatan kekafiran (seperti hadir di tempat-tempat orang-orang yang melakukan upacara kurban kepada Sangiang, ikut dalam pengobatan secara Balian dan sebagainya).

Apabila dari antara mereka ini ada yang masih melakukan praktik-praktik kehidupan lamanya, tidak diperkenankan ikut dalam pengajaran pembabtisan, walaupun orang tersebut meminta. Dengan demikian, segala sesuatu yang mengingatkan mereka dengan kehidupan lampaunya harus dibuang jauh-jauh. Demikian pula segala sesuatu yang berkaitan dengan adat istiadat dan tradisi suku harus diputuskan. Ketatnya aturan yang telah dikeluarkan gereja, mau tidak mau harus ditaati oleh mereka yang ingin dibaptis. Akibatnya, mereka yang baru dibaptis seolah-olah menjadi asing untuk dirinya sendiri dan harus mencari-cari identitasnnya. Kebudayaan asli milik mereka, baik yang positif maupun yang negatif harus dilepaskan dan dibuang semua. Seluruh akar kehidupan mereka yang berasal dari buminya sendiri telah dicabut, dibabat habis.

Tidak mengherankan apabila orang-orang Dayak yang telah menjadi Kristen dari generasi berikutnya, tidak lagi mengenal budaya dan asalusulnya. Mereka bahkan tidak mampu lagi mengungkapkan diri menggunakan unsur budaya leluhurnya. Mereka kini nyaris tercabut dari akar budaya leluhurnya. Hingga saat ini, dirasakan bahwa, tidak sedikit generasi muda terkena imbasnya. Mereka seolah telah kehilangan jati diri, hingga tak mampu lagi mengekspresikan diri sebagai orang Dayak.

Kekristenan dipandang sebagai tuas penghancur Kaharingan. Penyesuaian dan benturan dapat terjadi antara tradisi Dayak dengan kultur yang berbeda dari luar. Akibat perjumpaan itu, hampir tanpa kecuali, tradisi Dayak sedikit 
dipengaruhi. Ada berapa bentuk benturan tradisi di dalam satu masyarakat Sei Gohong. Pertama, benturan tradisi kesukuan dalam masyarakat Sei Gohong. Tradisi yang saling mendukung dapat saling memengaruhi, tergantung pada kekuatan relatif tradisi yang bersaing itu. Tradisi Dayak cukup kuat sehingga tradisi dari luar itu tidak banyak diserap oleh masyarakat Sei Gohong.

Kedua, intervensi pemerintah terhadap lembaga adat. Intervensi lembaga pemerintah terhadap lembaga tradisonal lembaga adat melalui Perda No. 16 tahun 2008 seakan mengamputasi peran Pemimpin adat (Demang). Inilah adalah jalan suram yang dilalui masyarakat Sei Gohong hari-hari yang akan datang. Sebagaimana dipahami, dalam Perda No. 16 tahun 2008, lembaga adat diintergrasikan ke dalam lembaga birokrasi pemerintahan modern. Banyaknya unsur lembaga modern yang masuk dalam substansi peran pemimpin adat dan memangkas perannya. Dengan demikian, baik secara institusi maupun secara substansi lembaga adat diamputasi oleh Peraturan Daerah tersebut. Figur kepala adat yang dahulu berdasarkan turun-temurun, kini siapa saja bisa menjadi demang.

Demang tidak lagi berdasarkan keturunan, tetapi dipilih dengan ketentuan yang diatur oleh undang-undang kenegaraan. PNS dapat menjadi demang. Rupanya pemerintah lebih dioreintasikan pada kemampuan intelektual demang daripada ketokohan dan karisma dalam penguasaan budaya Dayak. Cara kooptasi pemerintah Kalimantan Tengah untuk melemahkan posisi damang dan pemilik identitas Dayak.

Sedangkan secara kelembagaan, sebagaimana dijelaskan di atas, demang yang diintegrasikan dalan lembaga birokrasi menjadi contoh paling jelas dari perubahan kultural secara kualitatif di Sei Gohong. Kelembagaan demang dikooptasi menjadi bagian dari isntitusi modern yang bekerja dengan rasionalitas modern dan lebih fungsional sifatnya. Itu berarti meninggalkan gagasan khas lembaga demang yang lebih karismatik dan mempunyai kekuatan spiritual yang sanggup mempersatukan masyarakat dari semua latar belakang.

Ketiga, mentalitas Betang sebagai institusi pluralitas yang sudah mulai memudar. Betang (rumah panjang) rumah kolektif orang Dayak di mana di dalamnya hidup beberapa keluarga dengan keragaman baik personal maupun sosial. Dalam perspektif sosiologis orang Dayak, betang (rumah panjang), bukan sekedar tempat tinggal atau tempat berlindung (home stay), melainkan lebih itu betang adalah institusi yang membenihkan dan membina pranata sosial mikro (nilai, norma dan peran) dalam rangka memfasilitasi cara hidup bersama baik dalam rumah betang maupun dengan masyarakat luas.

Dapat dikatakan, watak dasar budaya betang adalah pluralisme. Dalil ini mudah dicarikan rujukan atau relevansinya dengan eksitensi betang (rumah panjang). Dalam betang berkumpul sejumlah keluarga yang berbeda baik secara persona, perbedaan kepentingan dalam tingkat praksis, perbedaan orientasi hidup maupun perbedaan suku. Dengan perkataan singkat, betang menjadi sumber sebuah pranata sosial dasar yang memberikan ruang dinamika pluarlitas dan sikap akomodatif orang Dayak.

Keadaan demikian, memperlihatkan betang sangat unik, terutama dalam perspektif pluralitas. Hidup bersama dalam peberdaan suku dan status sosial menjadi fenomena sosial yang menarik dalam betang. Mereka bertahan hidup dalam keragaman suku dalam serumah sebagai gejala betapa apiknya mekanisme sosial dan manajemen perbedaan dalam betang tersebut. Sejak kecil mereka diajarkan untuk menghormati orang lain, membantu sesama, diajarkan memahami hirarki dalam betang, santun dan lain sebagainya. Betang menjadi lembaga tempat membina dan membenihkan pranata sosial yang senagaja dikonstruksi untuk memfasilitasi cara hidup bersama dalam perbedaan. Betang, dengan kata lain, merupakan ruang tempat tumbuhnya pluralitas.

Sebagaimana dijelaskan di atas bahwa agama lokal Kaharingan dapat hidup dan 
berkembang di Sei Gohong karena selama ini kepercayaan Kaharingan sangat kuat mempengaruhi karakter sosial orang Dayak Ngaju di Sei Gohong. Kaharingan dipahami dan diamalkan sebagai bagian dari kebudayaan atau tradisi religi. Kepercayaan Ranying Hatalla Langit sebagai penguasa segala makhluk di bumi dan merupakan awal dan akhir semua kejadian di dunia. Ranying Hatalla Langit merupakan pewahyu ajaran bagaimana cara hidup di bumi yang kemudian dilembagakan dalam ritual.

Sudah berabad-abad lamanya, agama lokal Kaharingan sudah dipeluk oleh mayoritas masyarakat Sei Gohong. Sehingga ketika mereka memeluk agama di luar agama lokal Kaharingan, mereka tetap saja tidak dapat lepas dari prinsipprinsip hidup orang dayak yang selalu dilingkupi adat dan budaya Etnis Dayak Ngaju.

Kademangan yang dijadikan sebagai lembaga sosial sekaligus lembaga religius menjadi sumber terpenting dalam pranata sosial orang Dayak (di Sei Gohong). Sebagai institusi religius kedemangan dipandang sebagai titisan Ranying Hatalla. Lembaga ini yang paling langsung menginternalisasikan nilai-nilai kedayakan (peradaban Dayak). Di samping itu, lembaga kedemangan dapat membaptis orang luar menjadi orang Sei Gohong melalui mamapas lewu atau maja misek (nikah adat).

Dalam kasus Sei Gohong semua fenomena ini telah banyak berubah. Hasil observasi peneliti menunjukkan Gereja mempunyai andil besar untuk melenyapkan atau mendistorsi peradaban Dayak yang bersumber dari Ranying Hatalla. Kristen di kalimantan mengeluarkan aturan ungkup bahwa salah satu prasyarat pengajaran pembaptisan harus meninggalkan perbuatan kekafiran. Apabila dari antara mereka ini ada yang masih melakukan praktik-praktik kehidupan lamanya, tidak diperkenankan ikut dalam pengajaran pembaptisan. Segala sesuatu yang berkaitan dengan adat istiadat dan tradisi suku harus diputuskan.

Realitas Pademangan yang diintegrasikan dalan lembaga birokrasi menjadi penyebab terjadinya perubahan kultural Sei Gohong. Kelembagaan demang saat ini telah kehilangan kekhasannya sebagai lembaga yang karismatik dan mempunyai kekuatan spiritual yang sanggup mempersatukan masyarakat dari semua latar belakang.

Realitas saat ini, juga tidak ada lagi rumah betang yang menjadi lembaga yang membenihkan dan membina nilai hadat yang menjadi filsafat hidup orang dayak. Rumah-rumah di Sei Gohong memperlihatkan ambiguitas kultural. Pada satu pihak, rumah-rumah dibangun dengan kontruksi yang lebih modern, beratap seng dan berdinding semen. Tetapi kesan visual kedayakan masih terlihat. Sebagian besar rumah masih mempunyai kolong, bentuk memanjang (dua air), ada pula karing (kayu yang menyilang pada atap) dan ada juga ukiran burung tingang. Akan tetapi, unsurunsur arsitektur demikian menjadi tidak bermakna, dan hanya menjadi aksesoris sebagai kenangann rohaniah kedayakan masa lalu, karena rumahrumah mereka dihuni oleh keluarga tunggal atau keluarga inti yang lebih bersifat individualistik daripada kolektivitas. Dengan dengan demikian, tradisi-tridisi dan nilai-nilai kedayakan seperti harmoni dalam perbedaan, gotong-royong, menghargai hirarki, santun dan seterusnya mulai lantur. Orang Sei Gohong lebih berorientasi pada tawaran gaya hidup modern yang berorientasi pada praksis dan individualistik.

Konteks rumah panjang (betang) tidak hanya ukuran rumah yang panjang dan besar, tetapi keberadaan berbagai suku dan bagaimana mekanisme sosial di dalam rumah betang tersebut. Data yang dicatat kelurahan Sei Gohong misalnya terlihat rumah berdinding tembok 100 unit, berdinding kayu 252 unit. Terdapat 30 rumah berlantai keramik 30 rumah, berlantai semen 70 rumah; berlantai kayu 152 rumah. Terdapat 50 rumah beratap genteng, 150 beratap seng. Data ini memberikan indikasi bahwa Sei Gohong telah tercabut dari ke-Dayak-annya.

Hal penting lain bahwa kini orang Dayak, terutama di Sei Gohong yang penduduk aslinya 
tidak lagi menempati rumah betang. Mereka memiliki rumah secara individual yang terdiri atas suami, istri dan anak-anak mereka (keluarga inti). Dengan demikian, mekanisme sosial cenderung individualistik dan orang di luar rumah dipandang sebagai tetangga dan bukan warga betang.

Sei Gohong memasuki ruang individualistik dengan gaya hidup dan berorientasi pekerjaan mencari uang bukan mencari kebersamaan seperti kebiasaan di rumah betang. Ritual bersama, makan bersama, dan gotong-royong sangat jarang dilaksanakan. Padahal, betang merupakan tempat paling esensial mengkonstruksi nilai, norma dan aturan yang yang mempedomani bagaimana setiap anggota keluarga menjalani interaksi sehingga terjaga relasi sosial yang harmonis.

Sebagaimana telah dikemukakan pada bagian terdahulu, masyarakat Sei Gohong dewasa ini sedang bergerak dari old society menuju modern society. Perjalanan itu ditandai oleh pergeseran nilai dan makna hidup hari-hari. Hal yang paling muda dilihat ialah dikotomi individu berdasarkan orientasi pekerjaan mereka. Mereka lebih memilih bekerja di sektor informal dan mengurangi bekerja di sektor tradisonal seperti berladang dan nelayan. Orientasi ini sesungguhnya merupakan konsekuensi wajar oleh karena posisi geografis Sei Gohong yang demikian dekat dengan ibukota provinsi (Palangka Raya). Dapat dipahami bahwa kota sebagai pusat kemajuan sekaligus mempunyai daya tarik tersendiri bagi masyarakat sekitarnya, terutama penyediaan lapangan pekerjaan baik di sektor formal (PNS) maupun informal (swasta).

Keadaan demikian memperlihatkan bahwa mentalitas kapital dan individualitas makin menonjol. Anak-anak mudah di Sei Gohong lebih banyak bekerja di kota Palangka Raya sebagai buruh daripada menjadi petani di Sei Gohong. Pekerjaan di sektor informal atau sektor modern memerlukan spesifikasi dan kemampuan individualistik. Hal ini sangat berbeda dengan pekerjaan sektor tradisional yang yang lebih beroritesi pada kolektivitas.
Artinya, ketika kolektivitas yang melekat dalam pilihan pekerjaan sektor tradisional mulai memudar, maka sesungguhnya akibat yang paling dalam ialah runtuhnya rasa persaudaraan atau kebersamaan yang dibina sejak dari betang (rumah panujang) atau lamin (rumah panjang berukuran sedang) sampai seluas lewu (kampung). Lebih dari itu pudar kesadaran pluralitas yang dibenihkan di rumah betang.

Dengan perkataan lain, ketika adat tradisi tidak sanggup lagi menuntun mereka, atau nilainiloai tradisi mulai ditinggalkan, dan sementara mereka mulai berpikir dalam rasional praktis disertai ukuran materialisme dalam mensukseskan hidup, maka segala sesuatu yang kolektif mulai luntur. Bersamaan itu muncul hambatan sosial dalam hal kerukunan. Misalnya, perkawinan antara agama mulai rumit. Agama dipahami sebagai alkitabiah dan memberikan afirmasi berlebihan dalam hal diferensitasnya. Demikian halnya ketika lembaga adat melemah atau dikooptasi oleh pemerintah maka, birokrasi sebagai arus modern menjadi faktor pendukung kerentanan kerukunan dalam masyarakat Sei Gohong.

Demikian sulit dipastikan nasib kerukunan di Sei Gohong hari-hari mendatang. Arus kehidupan modern yang mengepungnya, dan proses penyingkiran budaya kolektif yang mengandalkan kebersamaan menjadi ancaman virus dalam kerukunan umat beragama.

Di samping itu, kehidupan politik memberikan penegasan pada segmentasi sosial. Masyarakat dengan tingkat kolektivitas dibenturkan dengan pilihan politik yang telah disediakan beradasarkan agama tertentu.

Kebudayakan Sei Gohong mempunyai pengaruh yang penting pada pluralitas agama. Sepanjang kedayakan dalam pengertian bahadat masih dipatuhi oleh masyarakat maka menjadi dasar interaksi harmonis antara individu dari komunitas keagamaan yang berbeda tersebut. Nilai, norma, dan sistem kepercayaan Dayak yang mempersatukan seluruh komunitas berbeda agama. Secara sosiologis kedayakan dapat memfasilitasi 
kehidupan keragaman yang memungkin semua suku yang berbeda agama merasa betah.

Dalam keseharian masyarakat Sei Gohong hidup secara berdampingan, tidak terlihat sikap eksklusifisme. Keadaan ini didukung pula oleh letak rumah mereka yang secara acak antara pemeluk agama yang berbeda. Bentuk kerja sama yang paling konkrit yang terlihat diakui oleh mereka ialah dalam hal membangun balai basara (rumah ibadah kepercayaan Kaharingan).

Dewasa ini pihak pemerintah cukup gencar mempromosikan untuk kembali ke Betang. Akan tetapi, promosi itu bukan kembali ke keloktivitas Dayak, tetapi rumah betang dalam artifisial yang rumah panjang dalam pengertian kekhasan dayak sebagai objek wisata. Dengan kata lain, itulah ironi baru, membangun betang untuk dipertontonkan kepada wisatawan. Sebuah rumah tanpa penguni dan roh yang hilang disapu zaman tanpa mempresentasikan identitas khas Dayak.

\section{KESIMPULAN DAN REKOMENDASI}

Berdasarkan hasil penelitian dapat disimpulan: Pertama, faktor pendukung keberadaan agama lokal Kaharingan dapat berkembang di Sei Gohong, Kecamatan Bukit Batu, Kota Palangka Raya, Kalimantan Tengah, Indonesia, yaitu: 1) adanya realitas bahwa kepercayaan Kaharingan sangat kuat mempengaruhi karakter sosial dan pranata sosial peradaban orang Dayak Ngaju, sehingga agama lokal Kaharingan menjadi pandangan hidup yang selalu diyakini oleh masyarakat dalam setiap melakukan tindakan, 2) agama lokal Kaharingan menjadi pusat sentuh agama-agama lain, artinya, meskipun orang etnis Dayak Ngaju telah memeluk agama lain selain agama lokal Kaharingan, akan tetapi seruluh perilaku dan keyakinannya tidak bisa lepas sama sekali dengan ajaran agama lokal Kaharingan, dan 3) adanya lembaga kademangan yang dipercayai sebagai lembaga sosial sekaligus lembaga religius. Lembaga adat inilah yang mampu menjadi pengayom bagi setiap masyarakat yang menghadapi berbagai permasalahan hidup.
Kedua, ada tiga faktor penghambat perkembangan agama lokal Kaharingan pada Etnis Dayak Ngaju, yaitu: 1) perubahan kultural. Masyarakat Sei Gohong dewasa ini sedang bergerak dari old society menuju modern society. 2) intervensi pemerintah terhadap lembaga adat yang disatukan dalam struktur birokrasi modern mengikuti undang-undang yang ada, dan 3) pudarnya mentalitas "betang". Rumah betang dalam artifiasial yang hanya dijadikan sebagai objek wisata. Rumah betang hanya untuk dipertontonkan kepada wisatawan tanpa makna dan identitas khas Dayak.

\section{E. REFERENSI}

Aslan, Adnan. 2004. Pluralisme Agama Dalam Filsafat Islam dan Kristen: Seyyed Hossein Nasr dan Jon Hick: Menyingkap Kebenaran. Bandung: Alifya.

Caputo, John D. 2003. Agama Cinta Agama Masa Depan. Bandung: Mizan.

Creswell W. John. 1998. Qualitative Inquiry and Risearch Design: Choosing Among Five Traditions. U.S.A.: SAGE Publications. Inc.

Herts, Jana C. 2003. Sekularisme dan Hak-Hak Individu dalam Usaha Melawan Diskriminasi Rasial dan Etnis di Indonesia dalam Antropologi Indonesia th.XXXVII, no.72.

Juliawan, B. Hari. Kutukan Menara Babel: Basis No 01-02 Tahun ke-53 Januari-Februari 2004. Yogyakarta: Kanisius.

Kimball Charles. 2003. Kala Agama Menjadi Bencana. Bandung: Mizan.

Nordholt, Schulte Henk. 2005.Outward Appearances: Trend, Identitas, Kepentingan. Diterjemahkan oleh M. Imam Aziz. Yogyakarta: LKIS.

O'Dea Thomas F. 2002. Agama Empiris: Agama dalam Pergumulan Realitas Sosial . Surabaya: Pustaka Pelajar dan PUSTAKA LP2IF.

Tubbs, Stewart L.\& Moss, Sylvia. 2000. Human Communication. Konteks-Konteks Komunikasi. Pengantar Deddy Mulyana. Bandung: Remaja Rosdakarya. 


\section{MEDIA505IAN}

Jurnal Ilmu Sosial dan Ilmu Administrasi Negara Vol. 2 No. 2

Tracy, David. 1987. Plurality and Ambiguity, Chicago Press.

Hermeneutic, Religion, Hope. University of 